\title{
VEHICLE RIDE HEIGHT CHANGE DUE TO RADIAL EXPANSION OF TIRES
}

\section{ONDŘEJ ČAVOJ, ONDŘEJ BLAŤÁK, PETR HEJTMÁNEK, JAN VANČURA}

Brno University of Technology, Faculty of Mechanical Engineering, Institute of Automotive Engineering Technická 2896/2, 61669 Brno, Tel.: +420 541142265

Email: cavoj@iae.fme.vutbr.cz, blatak@fme.vutbr.cz, hejtmanek@fme.vutbr.cz, vancura@fme.vutbr.cz

\section{SHRNUTÍ}

Při vývoji aerodynamiky automobilů zpravidla dochází k zanedbání deformace pneumatiky vlivem rotace kola. Tím, jak se s rostoucími otáčkami pneumatika obvodově rozpíná, ovlivňuje reálnou světlou výšku vozu za jízdy. Důsledkem může často být vyšší skutečný aerodynamický odpor ve srovnání s hodnotami získanými pomocí CFD nebo aerodynamického tunelu, což je dáno vyšším průtokem pod poměrně nerovnou podlahou vozu. $V$ rámci této práce byly změřeny prírůstky světlé výšky během jízd v přímém směru konstantní rychlostí, stejně jako aerodynamické vztlaky působící na vozidlo v tunelu. Dále byly stanoveny závislosti světlých výšek na zatižzení náprav pomocí prìdávání závaží do stojícího vozu. Porovnáním reálných hodnot světlé výšky ve vysokých a velmi nízkých rychlostech s předpokládanými změnami výšek danými aerodynamickým vztlakem spočítanými ze závislostí světlých výšek na zatižení náprav byla určena změna polohy karoserie způsobená obvodovým rozpínáním pneumatik.

KLIIČOVÁ SLOVA: AERODYNAMIKA VOZIDEL, DEFORMACE PNEUMATIKY, MĔ̌̌ENÍ ZA JIZZDY, LASEROVÝ SNÍMAČ VZDÁLENOSTI

\section{ABSTRACT}

In general, tire deformations caused by wheel rotation are not taken into account when developing vehicle aerodynamics. On the road the tires radially expand as speed increases, which affects the actual ride height of a vehicle. In turn this often increases the real aerodynamic drag compared to values obtained using CFD or a wind tunnel as the mass flow across the relatively rough underbody increases with ground clearance. In this study, on-road ride heights were measured while running a vehicle in a straight line with fixed velocity whilst the aerodynamic lift of the vehicle was determined in a wind tunnel. Subsequently, the relationships between ride height and axle load were obtained by loading the vehicle at standstill with ballast. By comparing the ride heights at high and very low velocities with expected vertical displacement caused purely by aerodynamic lift force as computed according to the ride height - axle load equations, the ride height change due to tire radial expansion was determined.

KEYWORDS: VEHICLE AERODYNAMICS, TIRE DEFORMATION, ON-ROAD MEASUREMENTS, LASER DISPLACEMENT TRANSDUCER

\section{INTRODUCTION}

In pursuit of lower emissions and better handling, modern vehicle aerodynamics development tends to incorporate ever finer details of what a car can experience in real-world conditions. In the computational area, this can involve the inclusion of various geometry details from a CAD model, the application of advanced turbulence models or the solving of various body motions and wheel rotation. The experimental part is usually carried out in a wind tunnel, where a vehicle is placed on a set of balances in a closed chamber, while a fan provides the necessary airflow. Here the focus is again very much on simulating body motions and correct underbody flow, but also on making the freestream airflow as similar to real world conditions as possible by using turbulence or cross wind generation systems [1]. Regarding the underbody flow, it is now more or less common practice to use a central moving belt on the floor and wheel drive units which allow for wheel rotation to ensure better correlation with on-road conditions. In addition, various suction or blowing systems can be used to influence the floor boundary layer $[2,3]$.

As demonstrated by Sapnaras and Dimitriou [4], aerodynamic development of the vehicle underbody area in wind tunnels using this equipment can generally be considered much more relevant to the real world environment than the older traditional 
approach with wheels and ground fixed. There are, however, still some discrepancies compared to on-road conditions which have to be taken into account. When simulating wheel rotation, the car is held in place by external struts emerging from the floor. These struts fix the position of the car body not only in the horizontal, but also in the vertical direction. Consequently, some differences from the real world are already bound to occur, as the car body is not able to move under the vertical forces acting upon it. Because road car bodies usually produce positive aerodynamic lift, the body is therefore being held lower than in a similar scenario on the road. Generally speaking, the result of the upward movement of the vehicle body is that both the aerodynamic lift and, possibly more importantly, the drag rise [5]. This can be caused, for example, by increased mass flow across the rough underbody area. Using the struts to fix the body may therefore result in an underestimation of aerodynamic drag in the wind tunnel.

Because the development of road cars often aims for a lift of close to zero, such limitation may not pose a problem in some cases, but as recently shown by Landström [6], there is yet another inevitable effect compounding the issue: the tire deformation. When the wheel rotates at higher speeds (typical velocities simulated in wind tunnels range from 100 $\mathrm{kph}$ to $160 \mathrm{kph}$ ), the tire shape changes quite significantly, as it undergoes axial compression and radial expansion as illustrated in Figure 1. The resulting lift of the wheel center at the aforementioned velocities can reach several millimeters, as shown in Figure 2. Coupled with the aerodynamic lift acting on the vehicle, this can cause a change in vehicle ride height that can't easily be neglected.

Further work has been done by Vdovin [7], who designed "floating struts" to allow for vertical travel of a vehicle body in a wind tunnel while still holding the car in position. By measuring the front and rear ride heights at several velocities with the tunnel fan switched on and off (wheels were rotating in all cases), he demonstrated that the radial expansion of the tires indeed forces the vehicle to rise (see Figure 3). Furthermore, with the wind on, the ride height now influenced by tire radial expansion and aerodynamic lift rose by roughly 8 millimeters at around $150 \mathrm{kph}$. Compared to the struts that fix the ride height, this is a significant difference.

Another effect of the radial expansion of the tire that potentially skews the results from the conventional tunnel with moving ground and fixed struts is the change in the ratio between wheel and wheel housing diameters. As shown, for example, by Regert [8], the aerodynamic drag of a vehicle decreases as the wheel diameter in a wheel housing of constant shape axial compression

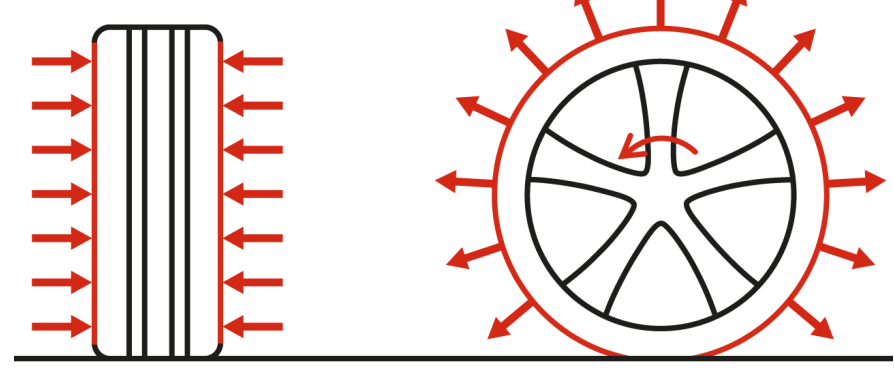

FIGURE 1: Definitions of tire deformations due to wheel rotation. OBRÁZEK 1: Definice deformací pneumatiky vlivem rotace kola.

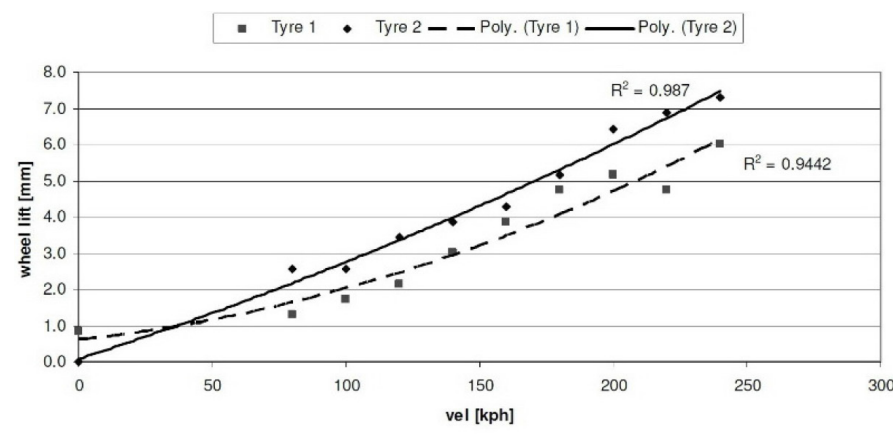

FIGURE 2: Vertical lift of the wheel center due to tire radial expansion for two different tires [6].

OBRÁZEK 2: Svislé zvedání středu kola vlivem obvodového rozpínání pro dvě odlišné pneumatiky [6].

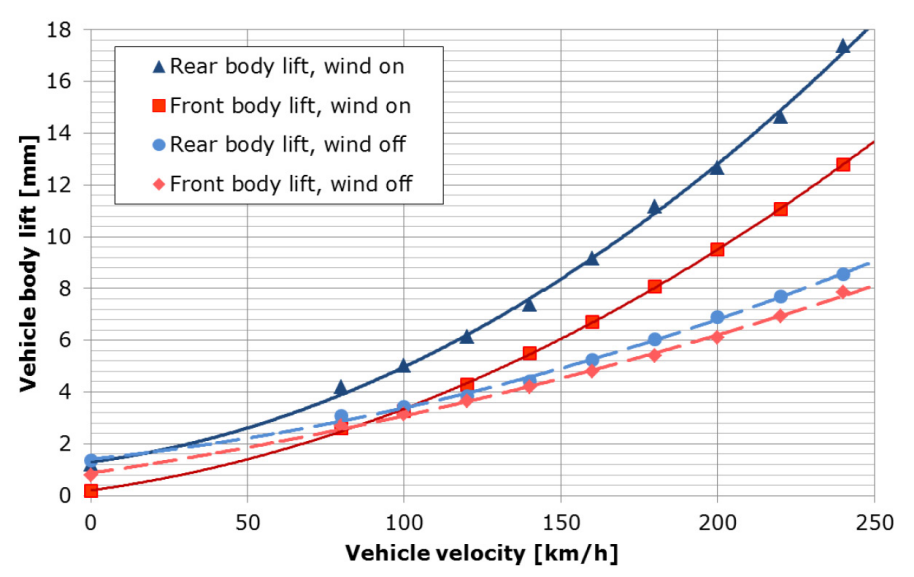

FIGURE 3: Comparison of front and rear vehicle body lifts in the wind tunnel with wind on and off [7].

OBRÁZEK 3: Srovnání zvedání přední a zadní části karoserie v aerodynamickém tunelu se zapnutým a vypnutým ventilátorem [7].

increases. This was also confirmed by Vdovin [7], who stated that with the vertical position of the body fixed, increasing velocities, i.e. increasing wheel diameter, cause the drag of the vehicle to decrease compared to the case where vertical displacement is allowed. 

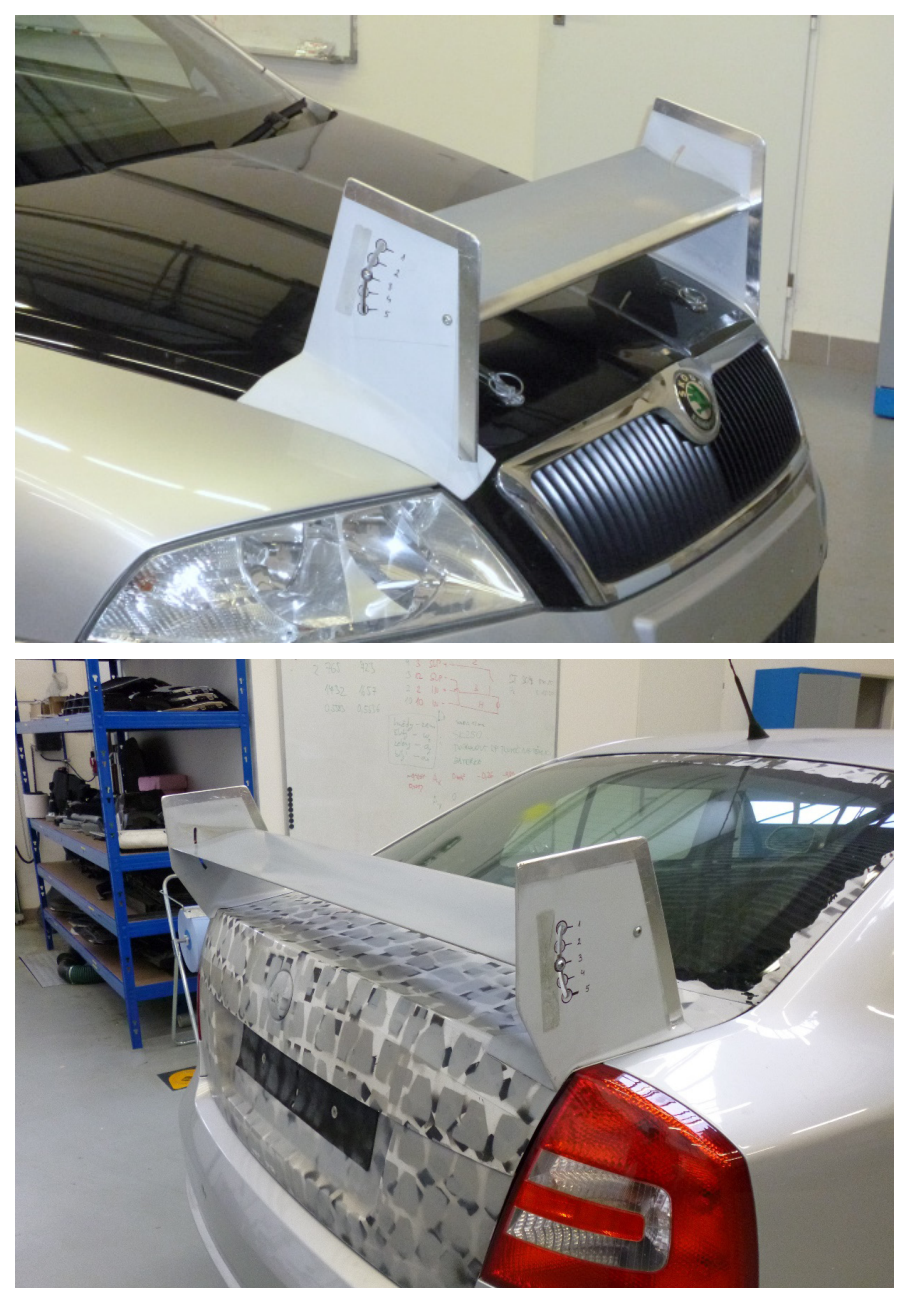

FIGURE 4: Škoda Octavia RS with adjustable wings on the bonnet and boot. OBRÁZEK 4: Škoda Octavia RS s nastavitelnými kř́dly na kapotě a víku zavazadlového prostoru.

This article aims to observe the phenomenon of radial tire expansion during on-road conditions by comparing the predicted vehicle ride heights based on data gathered in the wind tunnel and at standstill under different static loads with ride heights measured during straight line tests.

\section{METHODOLOGY}

The vehicle chosen for this work was a Škoda Octavia RS fitted with Dunlop SP Sport 01 225/50 R17 tires and equipped with wings on the bonnet and boot (shown in Figure 4). The angle of attack could be varied in several steps on both wings, which allowed the investigation of several aerodynamic configurations while keeping the mass distribution constant. In the first configuration, the front wing was set to high lift, while the rear wing was set to high downforce (i.e. negative lift). In three steps, making up a total of 4 configurations, the situation is gradually reversed to high front downforce and high rear lift. Aerodynamic forces for all configurations were determined in the VW wind tunnel without moving floor. The vehicle was therefore not fixed
TABLE 1: Coefficients of aerodynamic lift for different aerodynamic configurations.

TABULKA 1: Koeficienty aerodynamického vztlaku pro zkoumané aerodynamické konfigurace.

\begin{tabular}{|ccc|}
\hline Aerodynamic configuration & $\mathrm{C}_{\mathrm{LF}}$ & $\mathrm{C}_{\mathrm{LR}}$ \\
\hline AERO1 & 0,127 & $-0,065$ \\
AERO2 & 0,110 & 0,032 \\
AERO3 & 0,105 & 0,050 \\
AERO4 & 0,084 & 0,150 \\
\hline
\end{tabular}

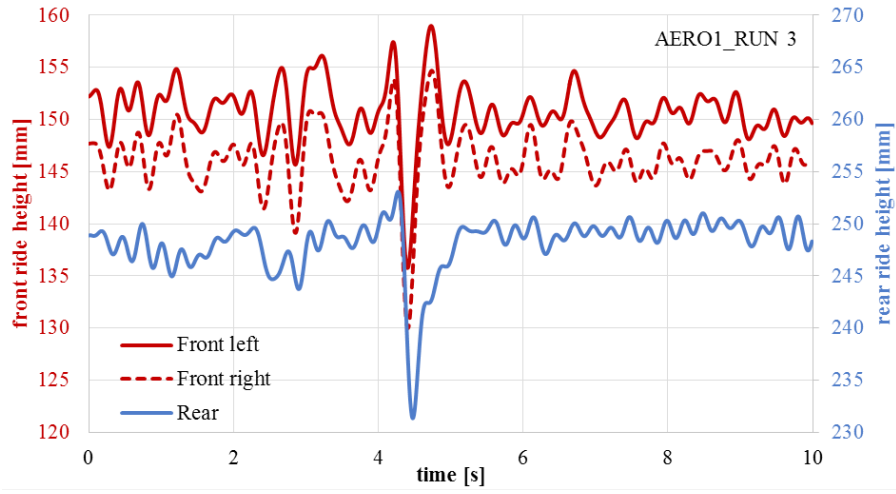

FIGURE 5: Ride height data trace sample from the straight line test. OBRÁZEK 5: Ukázka datového záznamu světlých výšek z jízdních zkoušek.
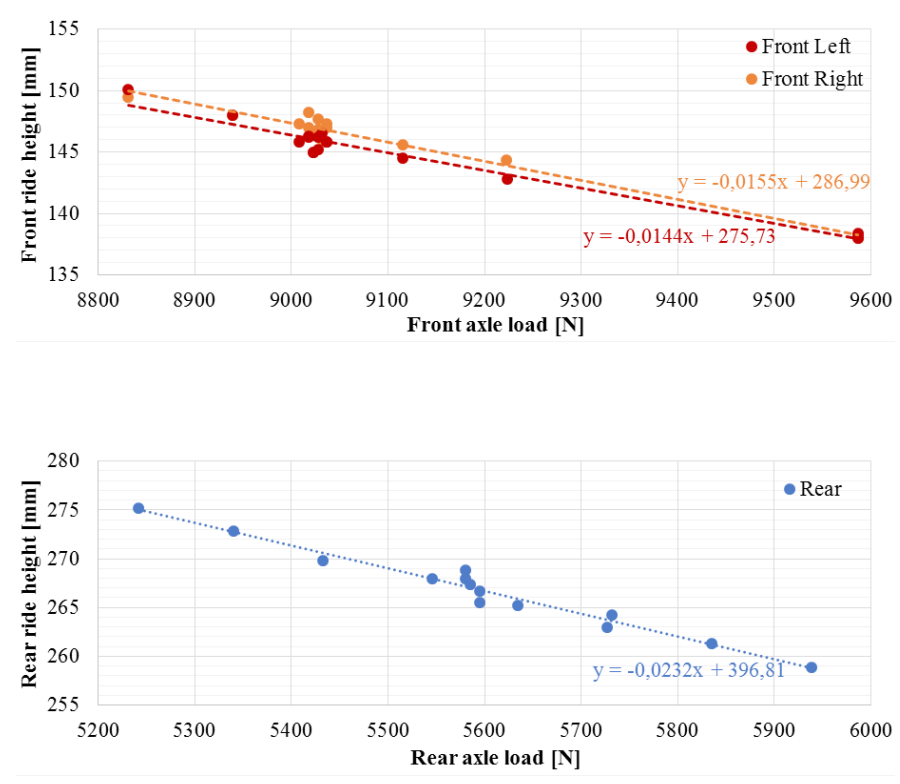

FIGURE 6: Axle load - ride height relationship obtained by loading the car with ballast.

OBRÁzEK 6: Vztah mezi zatížením nápravy a světlou výškou získaný prìdáváním závaží do vozu. 
by struts and the ride height could change under the influence of the actual aerodynamic forces. The wheels were not rotating, so the effect of tire radial expansion was not present. Lift coefficients for different wing settings are presented in Table 1.

Next, static front and rear ride heights were determined on the road while driving in a straight line with the vehicle velocity not exceeding $20 \mathrm{kph}$. This test was chosen as opposed to measurements with the vehicle at standstill to improve the accuracy by eliminating the effect of suspension friction, which can prevent a correct response of the vehicle ride height to a change in axle loads. The slight unevenness of the road surface allows the suspension to overcome this friction and the ride height settles in a more representative position. The final static ride height value is an average of 6 samples from separate tests, with the duration of each sample being at least 2 seconds.

The dynamic tests were conducted by driving in a straight line at a constant vehicle velocity of $140 \mathrm{kph}$ (the same as during the wind tunnel measurements) for at least 10 seconds. The test was repeated several times for each aerodynamic configuration and sections of data traces not influenced by road bumps were individually picked from each record. The ride heights presented are values averaged for a cumulative time of at least 15 seconds for each configuration. An example of one such data trace is shown in Figure 5.

Finally, a static method was used to determine the ride heights under different loads and derive an equation for the axle load - ride height relationship, which would be subsequently used to subtract the vertical displacement caused purely by aerodynamic lift from the overall ride height change. This was done by placing balances under each wheel and distributing ballast over front and rear axles to obtain ride heights under wheel loads comparable to those experienced during straight line driving, where they were measured using wheel force transducers. The equations obtained by linear regression can be seen in Figure 6 .

The ride heights were measured using laser displacement transducers placed on the underside of the car. At the front, ride heights were measured separately alongside each of the wheels, while rear ride height was measured in the middle of the track.

\section{RESULTS AND DISCUSSION}

In this chapter, the main results of the study are presented. Firstly, a prediction is provided of ride height change based on wind tunnel measurements and the axle load - ride height relationship equations. Next, a comparison of ride height change in the wind tunnel and on the road compared to static cases

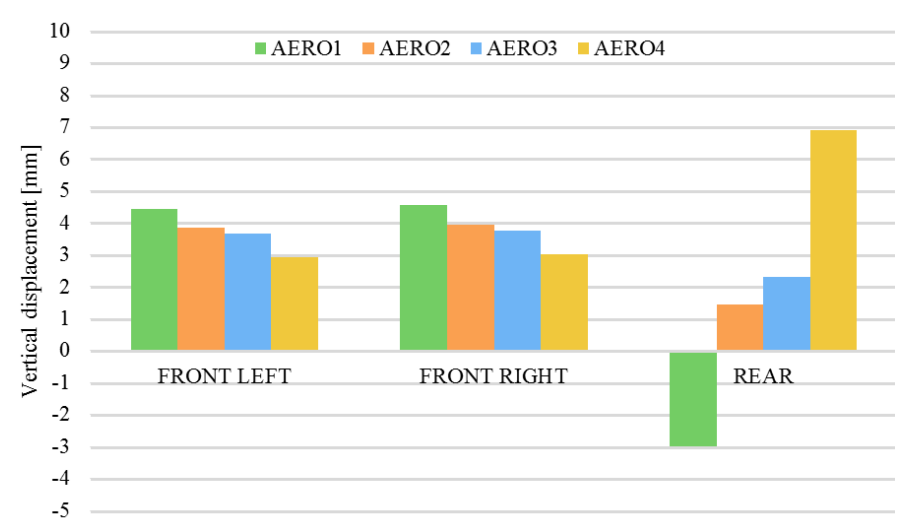

FIGURE 7: Predicted ride height changes due to aerodynamic lift. OBRÁZEK 7: Předpokládané změny světlých výšek způsobené aerodynamickým vztlakem.

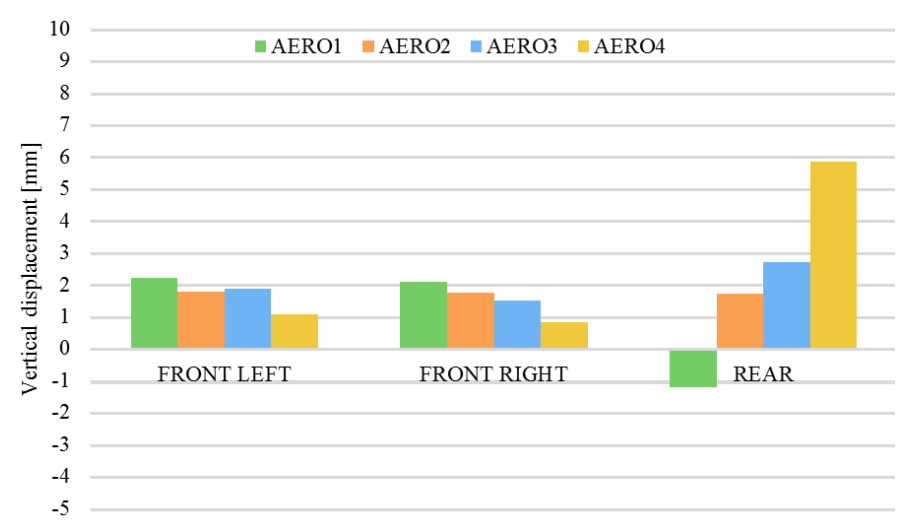

FIGURE 8: Ride height changes due to aerodynamic forces in the wind tunnel.

OBRÁZEK 8: Změny světlých výšek způsobené aerodynamickými silami v tunelu.

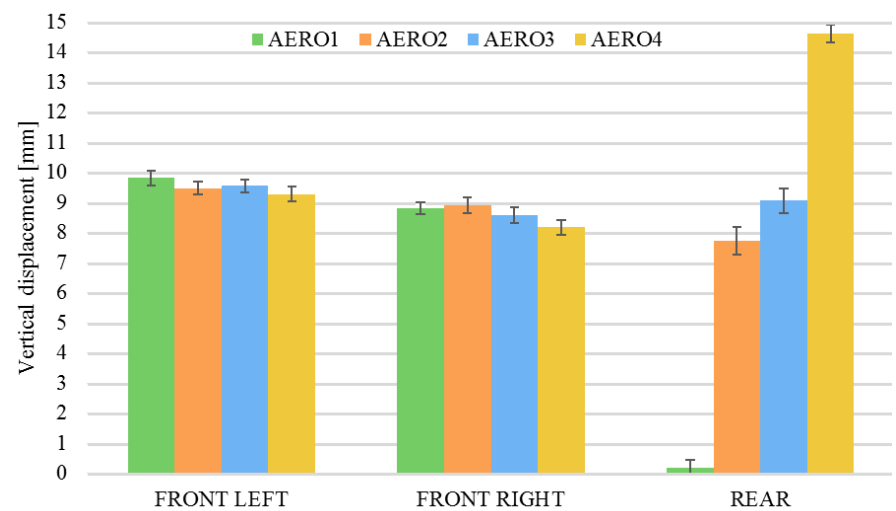

FIGURE 9: Ride height increments measured on the road including standard error bars.

OBRÁzEK 9: Přírůstky světlých výšek změřené za jízdy včetně chybových úseček. 


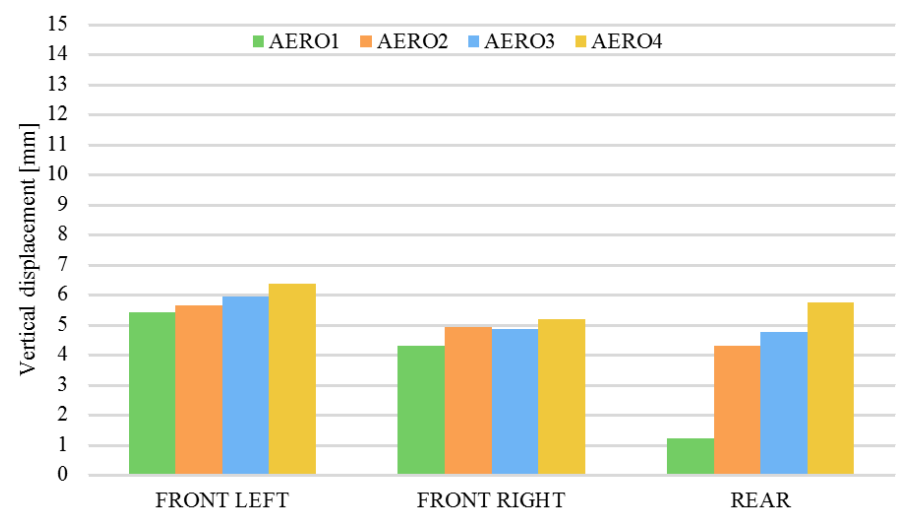

FIGURE 10: Differences between ride heights measured on the road and predictions based on aerodynamic forces caused by tire radial expansion.

OBRÁzEK 10: Rozdíly mezi světlými výškami v jízdních testech a světlými výskami predikovanými na základě aerodynamických sil způsobené obvodovým rozpínáním pneumatik.

is given. Finally, the differences are discussed, focusing on the evaluation of tire radial expansion.

The predicted changes in front and rear ride heights according to the aforementioned ride height equations and using wind tunnel data are shown in Figure 7. With the front axle subjected to positive lift in all configurations, the front ride heights are predicted to increase by 3 to 4 millimeters. On the rear axle, the predicted changes show significantly greater variance, with the first configuration producing negative lift and the range of lift coefficients being much wider. This is caused partly by the softer springs at the rear and partly by a greater effect of changing the incidence of the rear wing compared to the front wing.

In the wind tunnel, the actual measured differences between ride heights when the airflow is turned on and off follow the same trends, but the amount of vertical displacement is generally much lower (Figure 8). This can again be explained by friction in the suspension as mentioned in the previous section. While it may seem that the friction affects the front ride heights even more than those at the rear, it should be noted that the rear ride heights in the wind tunnel without moving ground simulation tend to increase as the airflow is turned on due to the transfer of longitudinal loads in the suspension. This situation is analogous to trying to reverse a car with the handbrake engaged. It is possible to avoid the effect by fixing the ride height, but that would be against the purpose of this work.

On the road the situation is quite different, as depicted in Figure 9. Whilst the correct trends are more or less preserved, the overall amount of vertical displacement is much higher. Compared to the reference values (gathered at very low velocities), the front ride heights increase by almost 10 millimeters, while at the rear, even the negative lift provided by the most aggressive wing settings does not cause the ride height to decrease, and the opposite wing settings result in a ride height almost 15 millimeters higher than at low speed.

When comparing predicted ride height changes due to aerodynamic lift force with measured data, it can be concluded that there is a noticeable offset, which corresponds to the assumption that realistic ride height on the road is higher than could be predicted purely from aerodynamic factors and that the prevalent cause of this can be found in the radial expansion of the tires. The differences shown in Figure 10 suggest that front ride heights are roughly 4 to 6 millimeters higher than the expected lift force would suggest. This also holds true in most cases for rear ride heights, apart from at the most aggressive wing settings. As there is also a noticeable trend at the rear indicating that the difference rises steeply as the rear lift force increases, the explanation for this may lie partly in the fact that the static measurements of ride height response to ballast were to some degree influenced by the suspension friction. The resulting equation for rear ride height change due to axle load might therefore not exactly correspond to the real world behavior. Furthermore, the results may be slightly skewed by the fact that aerodynamic forces were determined in the wind tunnel without moving ground simulation. The estimated error caused by this factor is in the region of $0.5 \mathrm{~mm}$ for the front axle and $1.0 \mathrm{~mm}$ for the rear axle.

Even with the slight discrepancies described taken into account, the additional vertical displacement in most cases still lies in the range of 4 to 6 millimeters, which corresponds well with the data obtained by Vdovin [7], where the vertical displacement due to tire radial expansion for a relevant velocity of $140 \mathrm{kph}$ is around 5 millimeters for both axles. It can therefore be concluded that the phenomenon in question can be held responsible for the fact that ride heights experienced by a car on the road are significantly higher than expected when only taking into account aerodynamic loading.

However, it also has to be noted that such a precise agreement with other measurements could be partly coincidental. As, for example, demonstrated by Landström [6], the amount of deformation also varies between different types of tire. An even greater influence can be expected from varying tire temperatures and therefore tire pressures during the tests, as shown by Vdovin [7]. Even though the temperature effect can theoretically be negated by allowing the tires to cool down between individual runs, this is often not very practical due to time limitations. And finally, the accuracy of the method used 
to determine ride height change due to aerodynamic loads on the road in this study is relatively low due to several factors, and should be regarded only as guidance. As was pointed out above, one has to consider the possible effect of suspension friction when measuring ride heights after loading the vehicle with ballast. Then there is a possible discrepancy between lift forces measured in the wind tunnel in a highly controlled environment and those experienced by the car on the road. This might be caused not only by differing ride heights or tire shape as described in this article, but also by varying freestream properties. While all of these effects would not be expected to completely buckle the trend, when combined, they could have an influence in the order of tenths of a millimeter or more.

\section{CONCLUSION}

The fact that tire shape changes as a car reaches a higher velocity is definitely no surprise. At the same time, however, it is a factor that is not usually taken into account in the aerodynamic development of a vehicle.

This study performed on the road confirmed previous wind tunnel results showing that the ride height can increase by several millimeters at velocities above $100 \mathrm{kph}$ purely because of the radial expansion of the tires due to inertial forces. These tire deformations were determined using an indirect approach by measuring front and rear ride heights with laser displacement transducers and subtracting the ride height increments due to aerodynamic lift based on wind tunnel data. For this purpose, four vehicle configurations with varying levels of aerodynamic lift were used.

The results show that the ride heights increase by about 4 to 6 millimeters on both axles solely because of the tire radial expansion, which is in excellent agreement with previous studies. Several minor areas of uncertainty were discussed, but none of them is expected to have an influence big enough to disapprove the overall findings.

As a consequence of disregarding such effect in CFD or wind tunnel development, the actual drag experienced by a car on the road would most probably be higher than predicted. In many cases, the same would be true for aerodynamic lift. For the end user this means higher energy consumption than stated in the vehicle technical specifications, even if only marginally. Furthermore, the tire deformation reduces the validity of the often accepted notion of a vehicle's aerodynamic coefficients being independent of Reynolds number.

\section{ACKNOWLEDGEMENTS}

Published results have been achieved thanks to the support from MEYS under National Sustainability Programme I (Project L01202) and the "Determination of aerodynamic loadings on a vehicle on road" project, registration number FV-14-13, granted by institutional university research of Brno University of Technology. This support is gratefully acknowledged.

\section{LIST OF NOTATIONS AND ABBREVIATIONS}

CFD Computational fluid dynamics

$C_{\mathrm{IF}} \quad$ coefficient of aerodynamic lift force on the front axle

$C_{I R} \quad$ coefficient of aerodynamic lift force on the rear axle

\section{REFERENCES}

[1] COGOTTI, A. Evolution of performance of an automotive wind tunnel. Journal of Wind Engineering and Industrial Aerodynamics. 2008, vol. 96, 6-7, s. 667-700. DOI: 10.1016/j.jweia.2007.06.007.

[2] DUELL, E. et al. The BMW AVZ Wind Tunnel Center. SAE Technical Paper 2010-01-0118. 2010.

[3] STERNÉUS, J., T. WALKER and T. BENDER. Upgrade of the Volvo Cars Aerodynamic Wind Tunnel. SAE Technical Paper 2007-01-1043. 2007.

[4] SAPNARAS, D. and I. DIMITRIOU. Experimental Analysis of the Underbody Pressure Distribution of a Series Vehicle on the Road and in the Wind Tunnel. SAE Technical Paper 2008-01-0802. 2008.

[5] HUCHO, W-H. Aerodynamics of Road Vehicles. 4 ed. Warrendale: Society of Automotive Engineers, 1998, $918 \mathrm{~s}$. ISBN 07-680-0029-7.

[6] LANDSTRÖM, C., L. JOSEFSSON, T. WALKER and L. LÖFDAHL. Aerodynamic Effects of Different Tire Models on a Sedan Type Passenger Car. SAE Technical Paper 2012-010169. 2012.

[7] VDOVIN, A., L. LÖFDAHL, S. SEBBEN and T. WALKER. Investigation of vehicle ride height and wheel position influence on the aerodynamic forces of ground vehicles. In: International Vehicle Aerodynamics Conference 2014. 2014.

[8] REGERT, T. and T. LAJOS. Description of flow field in the wheelhouses of cars. International Journal of Heat and Fluid Flow. 2007, vol. 28, issue 4, s. 616-629. DOI: 10.1016/j.ijheatfluidflow.2007.04.017. 